Cite this: RSC Adv., 2019, 9, 18963

Received 2nd May 2019

Accepted 31st May 2019

DOI: $10.1039 / c 9 r a 03275 d$

rsc.li/rsc-advances
Check for updates

\section{Effect of oxygen on power frequency breakdown voltage and decomposition characteristics of the $\mathrm{C}_{5} \mathrm{~F}_{10} \mathrm{O} / \mathrm{N}_{2} / \mathrm{O}_{2}$ gas mixture}

\author{
Yue Zhang, (D) ${ }^{a}$ Xiaoxing Zhang, (D) *ba Yi Li, (D) *a Yalong Li, (D) a Qi Chen, (D) ${ }^{a}$ \\ Guozhi Zhang, (D) ${ }^{b}$ Song Xiao (D) and Ju Tang (D) a
}

Sulfur hexafluoride $\left(\mathrm{SF}_{6}\right)$ is widely used in the power industry because of its excellent insulation and arc extinguishing performance; however, as the global environment is deteriorating, the need to replace $\mathrm{SF}_{6}$ is becoming significantly critical. In recent years, $\mathrm{C}_{5} \mathrm{~F}_{10} \mathrm{O}$ has received extensive attention as a potential alternative to $\mathrm{SF}_{6}$. In this study, a part of $\mathrm{N}_{2}$ in $\mathrm{C}_{5} \mathrm{~F}_{10} \mathrm{O} / \mathrm{N}_{2}$ was replaced by $\mathrm{O}_{2}$, and the breakdown voltages of $\mathrm{C}_{5} \mathrm{~F}_{10} \mathrm{O} / \mathrm{N}_{2} / \mathrm{O}_{2}$ at different oxygen concentrations under a slightly uneven electric field were tested. The dispersion of breakdown voltage and the discharge decomposition components of $\mathrm{C}_{5} \mathrm{~F}_{10} \mathrm{O} / \mathrm{N}_{2} / \mathrm{O}_{2}$ with different oxygen concentrations were analysed. It was found that as the oxygen concentration increased, the breakdown voltage of $\mathrm{C}_{5} \mathrm{~F}_{10} \mathrm{O} / \mathrm{N}_{2} / \mathrm{O}_{2}$ with $15 \mathrm{kPa} \mathrm{C}_{5} \mathrm{~F}_{10} \mathrm{O}$ at $0.2 \mathrm{MPa}$ increased, and the dispersion of the breakdown voltage became worse. When $0.5 \% \mathrm{O}_{2}$ or more $\mathrm{O}_{2}$ was added to the $\mathrm{C}_{5} \mathrm{~F}_{10} \mathrm{O} / \mathrm{N}_{2}$ gas mixture, the carbon precipitates on the electrode surface disappeared. As the oxygen concentration continued to increase, another characteristic component, $\mathrm{CF}_{2} \mathrm{O}$, could be detected, whereas $\mathrm{C}_{2} \mathrm{~F}_{4}$ and $\mathrm{C}_{3} \mathrm{~F}_{6}$ disappeared. It is believed that $\mathrm{O}_{2}$ can inhibit the formation of $\mathrm{C}_{2} \mathrm{~F}_{6}, \mathrm{C}_{3} \mathrm{~F}_{8}, \mathrm{C}_{4} \mathrm{~F}_{10}$, and $\mathrm{C}_{3} \mathrm{~F}_{7} \mathrm{H}$. Therefore, it is recommended to use oxygen as the second buffer gas for the engineering applications of $\mathrm{C}_{5} \mathrm{~F}_{10} \mathrm{O}$. Moreover, the ratio of $\mathrm{C}_{5} \mathrm{~F}_{10} \mathrm{O}$ to $\mathrm{O}_{2}$ is recommended to be $1: 1$.

\section{Introduction}

The gas insulated switchgear (GIS) has become an indispensable part of the power system due to its advantages such as small size and high operational reliability. ${ }^{1-5}$ Sulfur hexafluoride $\left(\mathrm{SF}_{6}\right)$ is widely used in the GIS as a gas insulating medium with high dielectric strength and excellent arc extinguishing performance. ${ }^{6-8}$ However, the global warming potential (GWP) value of $\mathrm{SF}_{6}$ is as high as 23 500, and its atmospheric lifetime is about 3200 years, $\mathrm{SF}_{6}$ is one of the most greenhouse gases. ${ }^{9-11}$ Therefore, the demand to limit the application of $\mathrm{SF}_{6}$ in the power industry is urgent. ${ }^{12-14}$ In this regard, researchers have paid significant attention to find alternative gases for $\mathrm{SF}_{6}$ from the perspective of insulation strength, environmental characteristics, decomposition properties as well as safety. Over the past three years, fluorocarbon macromolecules, such as c$\mathrm{C}_{4} \mathrm{~F}_{8}, \mathrm{CF}_{3} \mathrm{I}, \mathrm{C}_{4} \mathrm{~F}_{7} \mathrm{~N}, \mathrm{C}_{5} \mathrm{~F}_{10} \mathrm{O}$, and $\mathrm{C}_{6} \mathrm{~F}_{12} \mathrm{O}$, have attracted attention. ${ }^{15-25}$ Among these molecules, $\mathrm{C}_{5} \mathrm{~F}_{10} \mathrm{O}$ has shown significant advantages in terms of insulation strength, low GWP and reliable biosafety. The molecular structure of $\mathrm{C}_{5} \mathrm{~F}_{10} \mathrm{O}$ is shown in

${ }^{a}$ School of Electrical Engineering and Automation, Wuhan University, Wuhan 430072, China.E-mail: xiaoxing.zhang@outlook.com; liyi_whuee@163.com

${ }^{b}$ School of Electrical and Electronic Engineering, Hubei University of Technology, Wuhan 430072, China
Fig. $1 ; \mathrm{C}_{5} \mathrm{~F}_{10} \mathrm{O}$ is a non-toxic, colourless, and odourless substance.

Its chemical properties are stable; according to the data provided by $3 \mathrm{M}^{\mathrm{TM}}$, the initial decomposition temperature of $\mathrm{C}_{5} \mathrm{~F}_{10} \mathrm{O}$ is up to $600{ }^{\circ} \mathrm{C}$, whereas the temperature of the hottest spot in the equipment is usually less than $200{ }^{\circ} \mathrm{C} .{ }^{26}$ In addition, $\mathrm{C}_{5} \mathrm{~F}_{10} \mathrm{O}$ has the GWP of only 1 , and its atmospheric lifetime is only 14 days. Moreover, the ozone depletion potential (ODP)

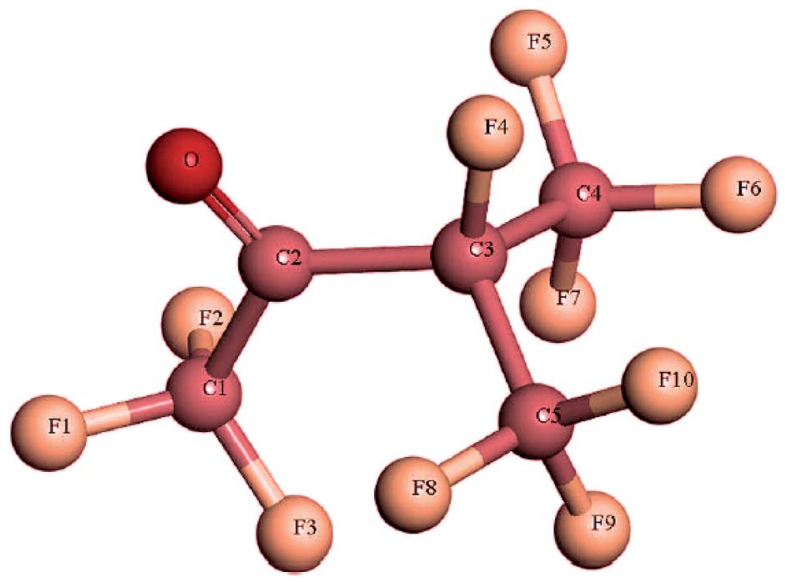

Fig. 1 Molecular structure of $\mathrm{C}_{5} \mathrm{~F}_{10} \mathrm{O}$. 
value of $\mathrm{C}_{5} \mathrm{~F}_{10} \mathrm{O}$ is zero; this means that $\mathrm{C}_{5} \mathrm{~F}_{10} \mathrm{O}$ does not consume the ozone layer of the atmosphere and fully meets the requirements of the "Montreal Protocol on Substances that Deplete the Ozone Layer". ${ }^{26}$ The insulation strength of pure $\mathrm{C}_{5} \mathrm{~F}_{10} \mathrm{O}$ is twice that of $\mathrm{SF}_{6}$; however, the liquefaction temperature of pure $\mathrm{C}_{5} \mathrm{~F}_{10} \mathrm{O}$ under normal pressure is high (i.e. $26.9^{\circ} \mathrm{C}$ ); therefore, it is usually mixed with a buffer gas that has very low liquefaction temperature during its research and practical application. ${ }^{27,28}$

Recently, several studies have been carried on $\mathrm{C}_{5} \mathrm{~F}_{10} \mathrm{O}$ gas mixtures. Saxegaard et al. have demonstrated that the use of $\mathrm{C}_{5} \mathrm{~F}_{10} \mathrm{O} /$ air with the liquefaction temperature of $-25{ }^{\circ} \mathrm{C}$ can increase the rated voltage of an air switchgear from $12 \mathrm{kV}$ to 24 $\mathrm{kV} .{ }^{29}$ In addition, it has been reported that the AirPlus ${ }^{\mathrm{TM}}$ ring network unit of $\mathrm{ABB}$ in the Netherlands meets the insulation expectations well and has no impact on the equipment life in the first year. ${ }^{30}$ Wang et al. tested the power-frequency (AC) breakdown characteristics of $\mathrm{C}_{5} \mathrm{~F}_{10} \mathrm{O} / \mathrm{CO}_{2}$ under a nonuniform electric field. They believe that the insulation performance of the gas mixture can be effectively improved by increasing the content of $\mathrm{C}_{5} \mathrm{~F}_{10} \mathrm{O} .{ }^{31}$ Aints et al. found that an increase in the content of $\mathrm{C}_{5} \mathrm{~F}_{10} \mathrm{O}$ in $\mathrm{C}_{5} \mathrm{~F}_{10} \mathrm{O}$ /air would reduce the effective ionization coefficient. ${ }^{32}$ Chachereau et al. have found that there is a significant synergy between $\mathrm{C}_{5} \mathrm{~F}_{12} \mathrm{O}$ and $\mathrm{N}_{2}$ or $\mathrm{CO}_{2}$, and the $\mathrm{C}_{5} \mathrm{~F}_{12} \mathrm{O}$ gas mixtures can reach the insulation strength requirement of $\mathrm{SF}_{6}$ by increasing the gas pressure. $^{33}$

In addition, it is important to study the decomposition characteristics of the $\mathrm{C}_{5} \mathrm{~F}_{10} \mathrm{O}$ gas mixtures. Our team calculated the decomposition mechanism of $\mathrm{C}_{5} \mathrm{~F}_{10} \mathrm{O}$ using density functional theory (DFT). It has been found that the activity of carbonyl in the $\mathrm{C}_{5} \mathrm{~F}_{10} \mathrm{O}$ molecule (as shown in Fig. 1) is strong. And, $\mathrm{C} 1-\mathrm{C} 2$ and $\mathrm{C} 2-\mathrm{C} 3$ in the $\mathrm{C}_{5} \mathrm{~F}_{10} \mathrm{O}$ molecule easily break to form $\mathrm{CF}_{3} \mathrm{CO}^{\cdot}$ and $\mathrm{C}_{3} \mathrm{~F}_{7} \cdot$ or $\mathrm{C}_{3} \mathrm{~F}_{7} \mathrm{CO}^{\cdot}$ and $\mathrm{CF}_{3} \cdot{ }^{34,35}$ Wang et al. have also explored the decomposition pathway of $\mathrm{C}_{5} \mathrm{~F}_{10} \mathrm{O}$ and pointed out that the $\mathrm{C} 2-\mathrm{C} 3$ and $\mathrm{C} 3-\mathrm{C} 4$ (or C3-C5) bonds in the $\mathrm{C}_{5} \mathrm{~F}_{10} \mathrm{O}$ molecule are more likely to break. ${ }^{18}$ The main decomposition components for the AirPlus ${ }^{\mathrm{TM}}$ switchgear after arc extinguishing are $\mathrm{CO}_{2}$, $\mathrm{CO}$, and $\mathrm{HF}$, among others, and it has been considered that the toxicity of the $\mathrm{C}_{5} \mathrm{~F}_{10} \mathrm{O}$ gas mixture is mainly determined by $\mathrm{CO}^{36}$ Hammer et al. detected the decomposition components of $\mathrm{C}_{5} \mathrm{~F}_{10} \mathrm{O} / \mathrm{N}_{2}$ under a dielectric barrier discharge. Several by-products such as $\mathrm{CO}, \mathrm{C}_{2} \mathrm{~F}_{6}$, and $\mathrm{C}_{3} \mathrm{~F}_{8}$ were detected. ${ }^{37}$

Previous studies have shown that the addition of $\mathrm{O}_{2}$ to a $\mathrm{C}_{5} \mathrm{~F}_{10} \mathrm{O} / \mathrm{CO}_{2}$ gas mixture can improve the insulation strength of the $\mathrm{C}_{5} \mathrm{~F}_{10} \mathrm{O}$ gas mixture. ${ }^{38}$ However, at present, only few studies have been reported on the influence of $\mathrm{O}_{2}$ on the insulation and decomposition properties of $\mathrm{a}_{5} \mathrm{~F}_{10} \mathrm{O}$ gas mixture. In this study, $\mathrm{C}_{5} \mathrm{~F}_{10} \mathrm{O}$ was mixed with $\mathrm{N}_{2}$, and $\mathrm{O}_{2}$ was added as the second buffer gas. By adjusting the oxygen concentration, the breakdown voltage and decomposition components of a $\mathrm{C}_{5} \mathrm{~F}_{10} \mathrm{O} / \mathrm{N}_{2} / \mathrm{O}_{2}$ ternary gas mixture after $\mathrm{AC}$ breakdown tests were investigated. The influence of oxygen on the insulation and decomposition properties of the $\mathrm{C}_{5} \mathrm{~F}_{10} \mathrm{O} / \mathrm{N}_{2} / \mathrm{O}_{2}$ gas mixture was explored first. Relevant results can provide reference for the engineering application of $\mathrm{C}_{5} \mathrm{~F}_{10} \mathrm{O}$ gas mixture.

\section{Test equipment, conditions and methods}

\subsection{Test equipment and conditions}

Fig. 2 shows the gas insulation performance and composition analysis platform. The output voltage of the high-voltage test transformer $(100 \mathrm{kV} / 0.5 \mathrm{~A})$ was adjusted by an induction voltage regulator. The AC voltage applied on the electrodes was measured by a voltage divider capacitor. Moreover, protective resistance $(10 \mathrm{k} \Omega$ ) was used to limit the short-circuit current during gap breakdown to prevent damage to the test transformer. Gas chromatography and mass spectrometry (GC/MS) were used for the qualitative analysis of the decomposition components.

A slightly uneven electric field is the most common electric field in the $\mathrm{SF}_{6}$ equipment. In the experiments to explore the insulation and decomposition characteristics of a potential $\mathrm{SF}_{6}$ substitute gas, sphere-sphere electrodes with the gap distance of $2 \mathrm{~mm}$ were used to simulate the slightly uneven electric field (the non-uniform coefficient of the electric field was calculated to be 1.02 by COMSOL Multiphysics with $E_{\max }=2.04 \times 10^{7} \mathrm{~V}$ $\mathrm{m}^{-1}$ and $E_{\mathrm{av}}=2 \times 10^{7} \mathrm{~V} \mathrm{~m}^{-1}$ ). The sphere-sphere electrodes are made of brass, and their radius is $25 \mathrm{~mm}$.

Although the insulation strength of the $\mathrm{C}_{5} \mathrm{~F}_{10} \mathrm{O}$ gas mixtures can be increased by increasing the content of $\mathrm{C}_{5} \mathrm{~F}_{10} \mathrm{O}$ in the gas mixture, high liquefaction temperature of $\mathrm{C}_{5} \mathrm{~F}_{10} \mathrm{O}$ under normal pressure will severely limit the application of $\mathrm{C}_{5} \mathrm{~F}_{10} \mathrm{O}$ in highvoltage gas insulation equipment. ${ }^{29}$ Exploration of the application of $\mathrm{C}_{5} \mathrm{~F}_{10} \mathrm{O}$ gas mixtures in medium-voltage or low-voltage gas insulated equipment (GIE) has become the focus of research in the industry. For this reason, all the experiments in this study were carried out under the condition of the absolute pressure of $0.2 \mathrm{MPa}$.

Considering the low liquefaction temperature of nitrogen and oxygen $\left(-140.7{ }^{\circ} \mathrm{C}\right.$ and $-118.57{ }^{\circ} \mathrm{C}$, respectively), the liquefaction temperature of $\mathrm{C}_{5} \mathrm{~F}_{10} \mathrm{O}$ gas mixture under normal pressure is determined by the partial pressure of $\mathrm{C}_{5} \mathrm{~F}_{10} \mathrm{O}$ in the gas mixture. ${ }^{39}$ In this study, the partial pressure of $\mathrm{C}_{5} \mathrm{~F}_{10} \mathrm{O}$ was set to $15 \mathrm{kPa}$, and the corresponding liquefaction temperature

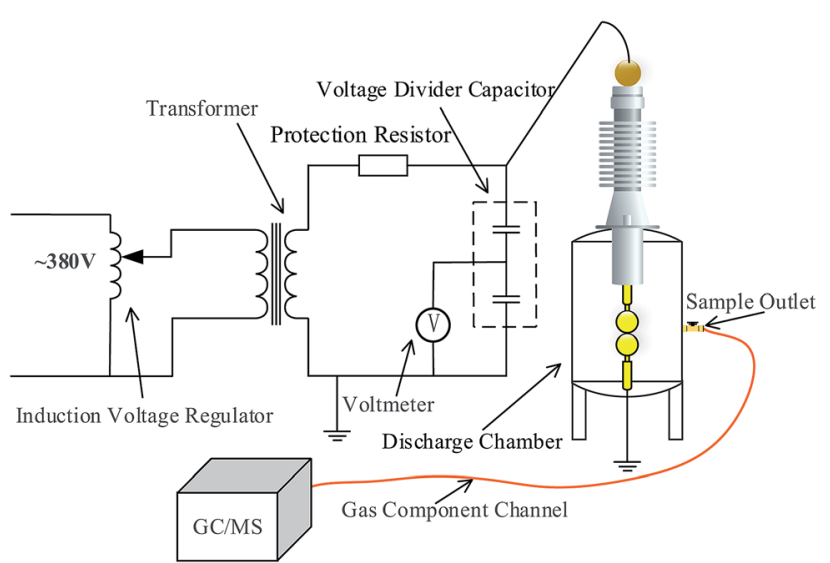

Fig. 2 Gas insulation performance test and gas composition analysis platform. 
of the gas mixtures was $-15{ }^{\circ} \mathrm{C}$. In addition, because the pressure remains unchanged, the addition of oxygen will reduce the nitrogen concentration accordingly.

To investigate the effect of oxygen concentration on the breakdown voltage and decomposition characteristics of $\mathrm{C}_{5} \mathrm{~F}_{10} \mathrm{O} / \mathrm{N}_{2} / \mathrm{O}_{2}$, herein, four groups of gas mixtures with the oxygen concentrations of $0 \%, 0.5 \%, 7.5 \%$ and $19.33 \%$ were tested. The corresponding partial pressure of oxygen was $1 \mathrm{kPa}$ when the oxygen concentration was $0.5 \%$. The oxygen concentration of $7.5 \%$ corresponded to the oxygen partial pressure of $15 \mathrm{kPa}$ (i.e. $\mathrm{C}_{5} \mathrm{~F}_{10} \mathrm{O}: \mathrm{O}_{2}$ was equal to $1: 1$ ), and when the oxygen concentration was $19.33 \%$, the partial pressure of oxygen was $38.66 \mathrm{kPa}$ (actually, it was a gas mixture of $\mathrm{C}_{5} \mathrm{~F}_{10} \mathrm{O}$ and air).

\subsection{Test methods}

The gas chamber was vacuum-pumped and then filled with buffer gas until the absolute pressure was greater than 0.2 MPa. Then, the abovementioned steps were repeated three times to ensure that each test was unaffected by previous tests and other impurities in the chamber. Because of the low saturated vapor pressure of $\mathrm{C}_{5} \mathrm{~F}_{10} \mathrm{O}$ at normal temperature, it should be filled into the chamber first followed by oxygen and nitrogen. It was necessary to stand the gas mixture for 24 hours to make it mix evenly. The power frequency voltage was applied to the discharge chamber by a step-up method with a gap of at least 5 minutes between every two breakdowns. A total of 60 breakdown tests were conducted for each group of gas mixture. The average value of the breakdown voltage of the first ten breakdowns was taken as the breakdown voltage of $\mathrm{C}_{5} \mathrm{~F}_{10} \mathrm{O} / \mathrm{N}_{2} / \mathrm{O}_{2}$ under each oxygen concentration condition.

The $\mathrm{C}_{5} \mathrm{~F}_{10} \mathrm{O} / \mathrm{N}_{2} / \mathrm{O}_{2}$ samples after 60 times breakdown were obtained and tested by GC/MS. Moreover, the qualitative analysis of the gas was carried out by comparing the scanned results of the standard gas chromatography with the standard chromatographic database of the National Institute of Standards and Technology (Nist14.0).

\section{Test results and analysis}

\subsection{Effect of oxygen concentration on the breakdown voltage of $\mathrm{C}_{5} \mathrm{~F}_{10} \mathrm{O} / \mathrm{N}_{2} / \mathrm{O}_{2}$}

As shown in Fig. 3, the breakdown voltage of $\mathrm{C}_{5} \mathrm{~F}_{10} \mathrm{O} / \mathrm{N}_{2} / \mathrm{O}_{2}$ increases with the increasing oxygen concentration. The electronegativity of oxygen is greater than that of nitrogen, and its ability to attract electrons is stronger; thus, oxygen is more likely to hinder the development of discharge. Therefore, in the case of constant pressure and $\mathrm{C}_{5} \mathrm{~F}_{10} \mathrm{O}$ concentration, the dielectric strength of the $\mathrm{C}_{5} \mathrm{~F}_{10} \mathrm{O}$ gas mixture will increase with the increasing oxygen content.

Fig. 4 shows the breakdown voltage values of $\mathrm{C}_{5} \mathrm{~F}_{10} \mathrm{O} / \mathrm{N}_{2} / \mathrm{O}_{2}$ for 60 breakdown tests under different oxygen concentration conditions. Due to the random nature of discharge, the standard deviation is defined to characterize the dispersion of the breakdown voltage of $\mathrm{C}_{5} \mathrm{~F}_{10} \mathrm{O} / \mathrm{N}_{2} / \mathrm{O}_{2}$ at different oxygen concentrations. The formula for the calculation is as follows:

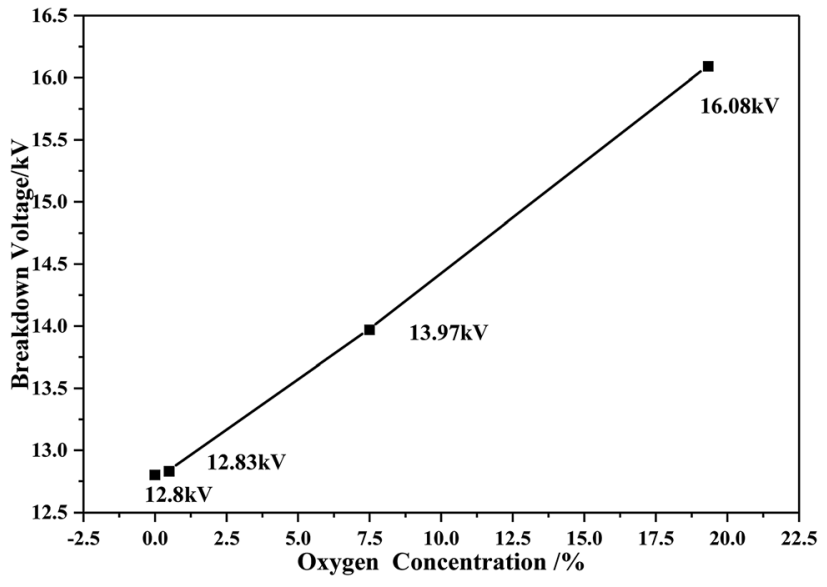

Fig. 3 Relationship between the oxygen concentration and breakdown voltage of $\mathrm{C}_{5} \mathrm{~F}_{10} \mathrm{O} / \mathrm{N}_{2} / \mathrm{O}_{2}$.

$$
\sigma=\sqrt{\frac{1}{N-1} \sum_{i=1}^{N}\left(x_{i}-\bar{x}\right)^{2}}
$$

where $N$ is the number of samples $(N=60), x_{i}$ is the breakdown voltage value of the $i$ th time, $\bar{x}$ is the average value, and $\sigma$ is the standard deviation of the breakdown voltage of the experimental set.

When the oxygen concentration was $0 \%$, the breakdown voltages of $\mathrm{C}_{5} \mathrm{~F}_{10} \mathrm{O} / \mathrm{N}_{2} / \mathrm{O}_{2}$ for 60 times breakdown were around $12.8 \mathrm{kV}$ with $\sigma=0.40$. For gas mixture with $0.5 \%$ oxygen, a few data points deviated from $12.83 \mathrm{kV}$, and $\sigma=$ 0.46 ; with an increase in the oxygen concentration to $7.5 \%$, the amount of the breakdown voltage data deviating from $13.97 \mathrm{kV}$ increased, and $\sigma=0.83$. When the oxygen concentration gradually increased to $19.33 \%$, most of the breakdown voltage values deviated from $16.08 \mathrm{kV}$, and $\sigma=1.08$.

Overall, the breakdown voltage of $\mathrm{C}_{5} \mathrm{~F}_{10} \mathrm{O} / \mathrm{N}_{2} / \mathrm{O}_{2}$ increased as the oxygen concentration increased; however, most of the breakdown voltage data deviated from the average breakdown voltage values, and $\sigma$ became larger; this indicated that the dispersion of gas insulation strength gradually became worse.

\subsection{Effect of oxygen concentration on the decomposition characteristics of $\mathrm{C}_{5} \mathrm{~F}_{10} \mathrm{O} / \mathrm{N}_{2} / \mathrm{O}_{2}$}

Fig. 5 and 6 show the detection results of the $\mathrm{C}_{5} \mathrm{~F}_{10} \mathrm{O} / \mathrm{N}_{2} / \mathrm{O}_{2}$ components before and after breakdown obtained by GC/MS in the SCAN mode. As shown in Fig. 5, there are no other impurities in the gas.

Fig. 6 shows the component detection results of the $\mathrm{C}_{5} \mathrm{~F}_{10} \mathrm{O}$ gas mixture with different oxygen concentrations after 60 times breakdown. Since no substance is detected before $4.4 \mathrm{~min}$ and after $7 \mathrm{~min}$, to facilitate the description of the discharge decomposition components of the $\mathrm{C}_{5} \mathrm{~F}_{10} \mathrm{O}$ gas mixture, only the GC/MS scan results from 4.25 to 6.25 min are shown in Fig. 6 . Considering that the breakdown voltage is positively related to the energy generated during breakdown, we have plotted the scanning results of the discharge decomposition components of 


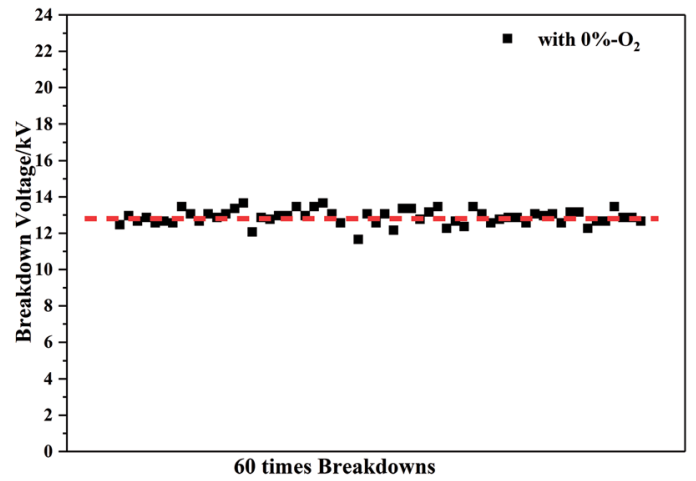

(a)

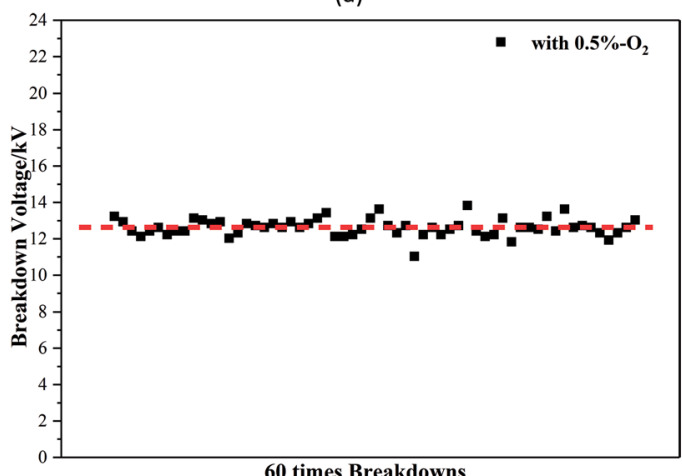

(b)

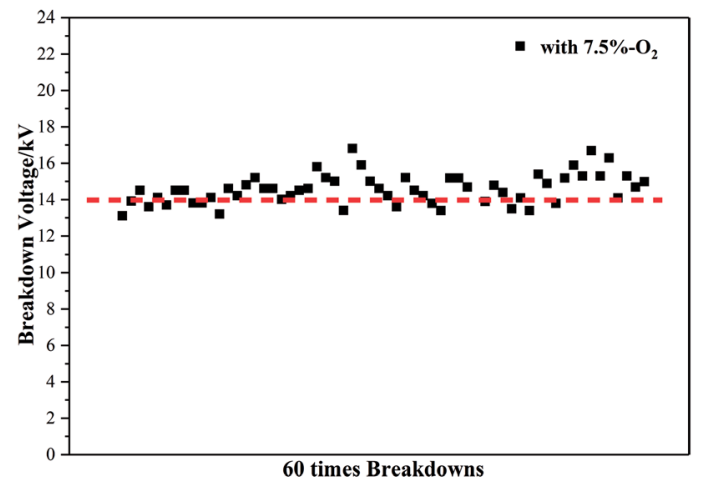

(c)

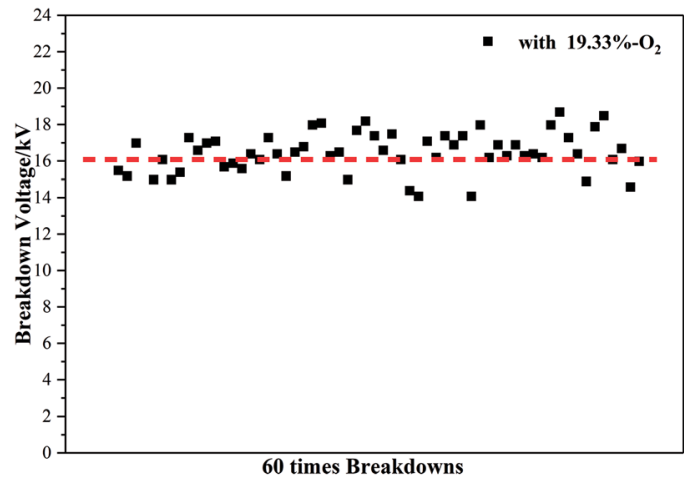

(d)

Fig. 460 times breakdown voltage of $\mathrm{C}_{5} \mathrm{~F}_{10} \mathrm{O} / \mathrm{N}_{2} / \mathrm{O}_{2}$ under different oxygen concentrations.

the $\mathrm{C}_{5} \mathrm{~F}_{10} \mathrm{O}$ gas mixture at different oxygen concentrations in the same figure in turn. Therefore, the yield of each component can be compared intuitively by the peak area of each component.

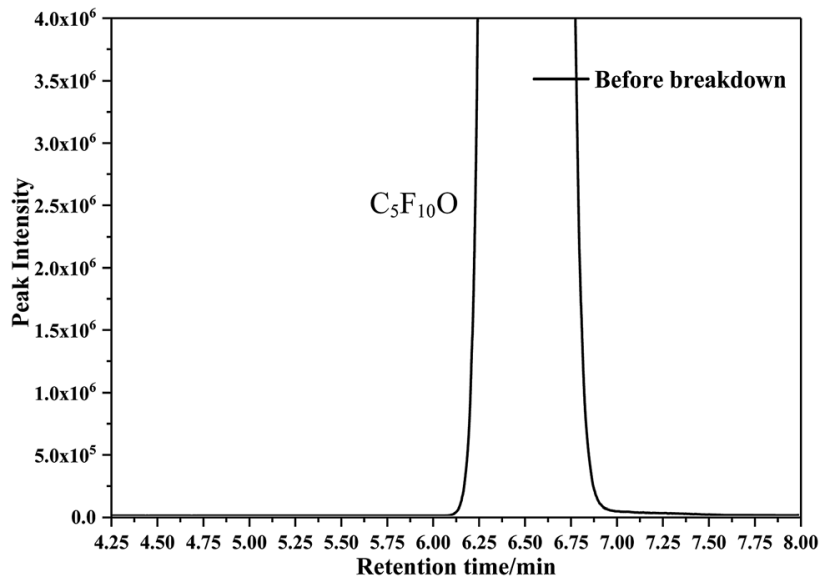

Fig. 5 Components before breakdown.

As shown in Fig. 6a, when the oxygen concentration was $0 \%$, the characteristic peaks of $\mathrm{CF}_{4}, \mathrm{C}_{2} \mathrm{~F}_{6}, \mathrm{C}_{3} \mathrm{~F}_{8}, \mathrm{C}_{2} \mathrm{~F}_{4}, \mathrm{C}_{4} \mathrm{~F}_{10}, \mathrm{C}_{3} \mathrm{~F}_{6}$ and $\mathrm{C}_{3} \mathrm{~F}_{7} \mathrm{H}$ were found. Moreover, the peak area of $\mathrm{C}_{2} \mathrm{~F}_{6}$ is largest. The peak area of $\mathrm{CF}_{4}$ is significantly less than that of $\mathrm{C}_{2} \mathrm{~F}_{6}$. However, when $0.5 \%$ oxygen was added to the gas mixture, the content of $\mathrm{C}_{3} \mathrm{~F}_{7} \mathrm{H}$ was reduced relative to the case when the oxygen concentration was $0 \%$. The content of other components is close to that of the $\mathrm{C}_{5} \mathrm{~F}_{10} \mathrm{O}$ gas mixture without oxygen.

As shown in Fig. 6b, when the oxygen concentration is increased from $0.5 \%$ to $7.5 \%$, the content of $\mathrm{C}_{2} \mathrm{~F}_{6}$ is greatly reduced, and the peak area of $\mathrm{CF}_{4}$ is close to that of $\mathrm{C}_{2} \mathrm{~F}_{6}$. Moreover, the contents of $\mathrm{C}_{3} \mathrm{~F}_{8}$ and $\mathrm{C}_{4} \mathrm{~F}_{10}$ are greatly reduced. In addition, $\mathrm{C}_{2} \mathrm{~F}_{4}$ and $\mathrm{C}_{3} \mathrm{~F}_{6}$ are not detected in the gas mixture with $7.5 \%$ oxygen, and a small amount of $\mathrm{CF}_{2} \mathrm{O}$ is detected at $4.757 \mathrm{~min}$. The content of $\mathrm{CO}_{2}$ increased when compared with that of the gas mixture with $0.5 \%$ oxygen. The contents of most of the decomposition components of the $\mathrm{C}_{5} \mathrm{~F}_{10} \mathrm{O}$ gas mixture with $7.5 \%$ oxygen are lower than those of the gas mixture with $0.5 \%$ oxygen, except for $\mathrm{CF}_{2} \mathrm{O}$ and $\mathrm{CO}_{2}$. Thus, the addition of oxygen inhibits the formation of macromolecules such as $\mathrm{C}_{2} \mathrm{~F}_{6}$, $\mathrm{C}_{3} \mathrm{~F}_{8}, \mathrm{C}_{4} \mathrm{~F}_{10}$, and $\mathrm{C}_{3} \mathrm{~F}_{7} \mathrm{H}$.

As shown in Fig. 6c, when the oxygen content increases from $7.5 \%$ to $19.33 \%$, the peak area of $\mathrm{CF}_{4}$ is closer to that of $\mathrm{C}_{2} \mathrm{~F}_{6}$. The peak areas of $\mathrm{CF}_{4}, \mathrm{C}_{2} \mathrm{~F}_{6}, \mathrm{CF}_{2} \mathrm{O}, \mathrm{C}_{3} \mathrm{~F}_{8}, \mathrm{CO}_{2}, \mathrm{C}_{4} \mathrm{~F}_{10}$ and $\mathrm{C}_{3} \mathrm{~F}_{7} \mathrm{H}$ increased to different extents. Among them, the peak area of $\mathrm{CF}_{2} \mathrm{O}$ is significantly increased. Note that oxygen cannot be considered to promote the production of $\mathrm{C}_{2} \mathrm{~F}_{6}, \mathrm{C}_{3} \mathrm{~F}_{8}, \mathrm{C}_{4} \mathrm{~F}_{10}$, etc. As the oxygen concentration increases, the breakdown voltage increases as well; thus, the greater energy generated during the discharge breakdown causes more $\mathrm{C}_{5} \mathrm{~F}_{10} \mathrm{O}$ to decompose; this results in an increase in the decomposition of the $\mathrm{C}_{5} \mathrm{~F}_{10} \mathrm{O}$ gas mixture.

To more clearly illustrate the inhibitory effect of oxygen on the formation of $\mathrm{C}_{2} \mathrm{~F}_{6}, \mathrm{C}_{3} \mathrm{~F}_{8}, \mathrm{C}_{4} \mathrm{~F}_{10}$ and $\mathrm{C}_{3} \mathrm{~F}_{7} \mathrm{H}$, the results of the decomposition components of the $\mathrm{C}_{5} \mathrm{~F}_{10} \mathrm{O}$ gas mixtures with the oxygen concentrations of $0 \%$ and $19.33 \%$ were compared, as shown in Fig. 7.

As shown in Fig. 6c, when the oxygen concentration increased from $7.5 \%$ to $19.33 \%$, the breakdown voltage 


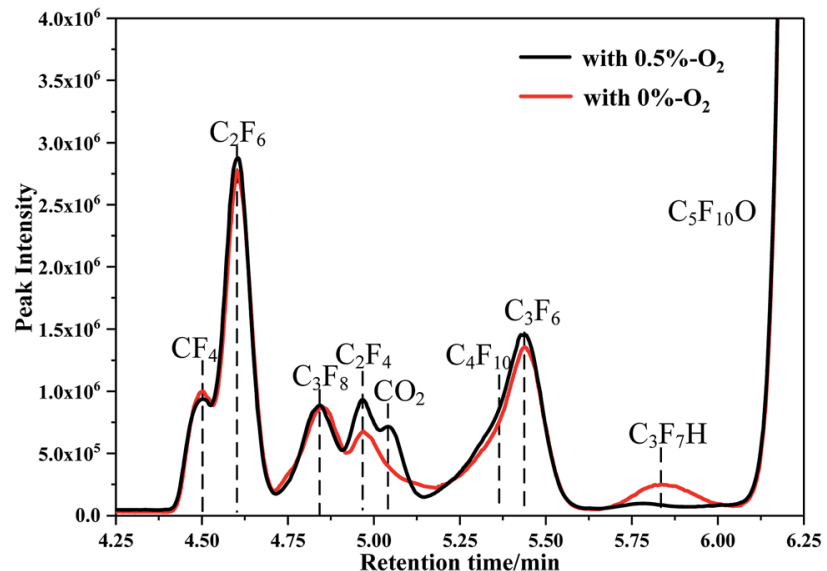

(a)

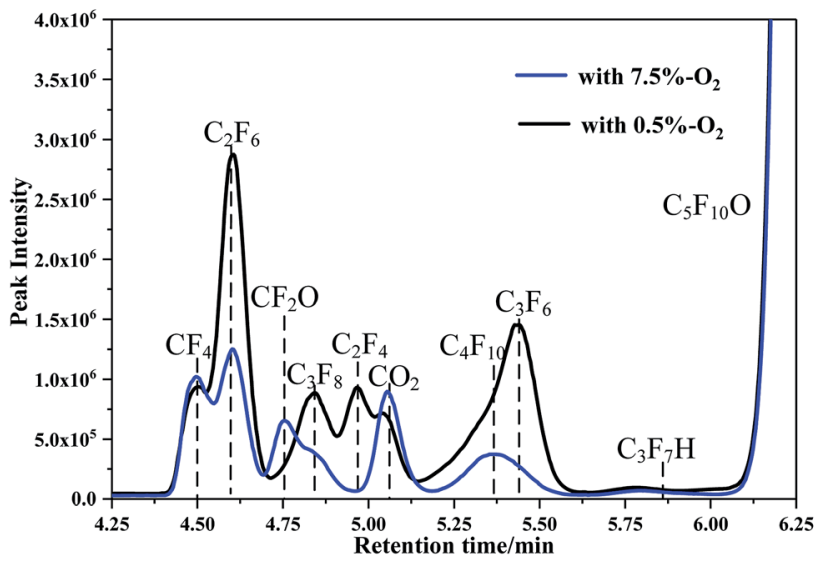

(b)

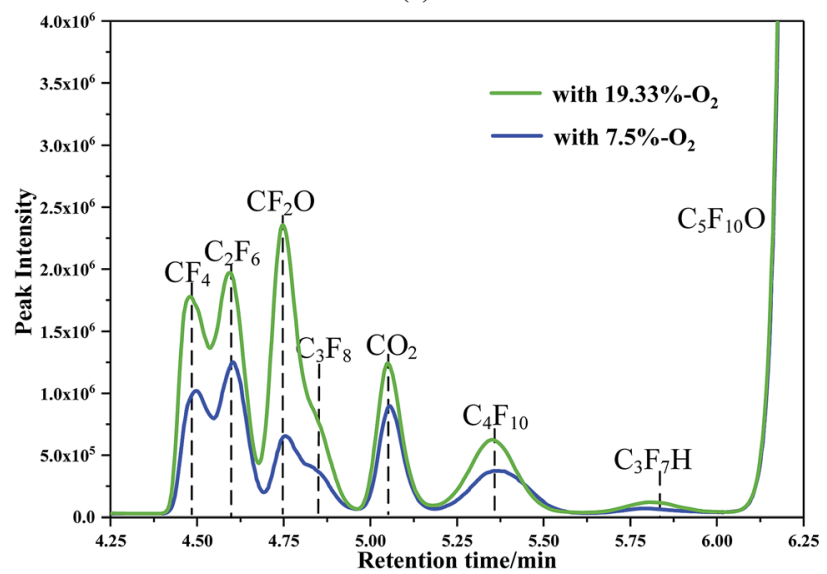

(c)

Fig. 6 Components after 60 times breakdown with different oxygen concentrations.

increased by $2.11 \mathrm{kV}$; this resulted in a significant increase in the contents of the decomposition components of the $\mathrm{C}_{5} \mathrm{~F}_{10} \mathrm{O}$ gas mixture. However, as shown in Fig. 7, the breakdown voltage of $\mathrm{C}_{5} \mathrm{~F}_{10} \mathrm{O} / \mathrm{N}_{2}$ increased from $12.8 \mathrm{kV}$ to $16.08 \mathrm{kV}$ (an increase by $3.28 \mathrm{kV}$ ) when the oxygen concentration was increased from $0 \%$ to $19.33 \%$. However, the contents of $\mathrm{C}_{2} \mathrm{~F}_{6}, \mathrm{C}_{3} \mathrm{~F}_{8}, \mathrm{C}_{4} \mathrm{~F}_{10}$ and $\mathrm{C}_{5} \mathrm{~F}_{12}$ for the $\mathrm{C}_{5} \mathrm{~F}_{10} \mathrm{O}$ gas mixture with $19.33 \%$ oxygen were not more than those of the $\mathrm{C}_{5} \mathrm{~F}_{10} \mathrm{O}$ gas mixture without oxygen addition.

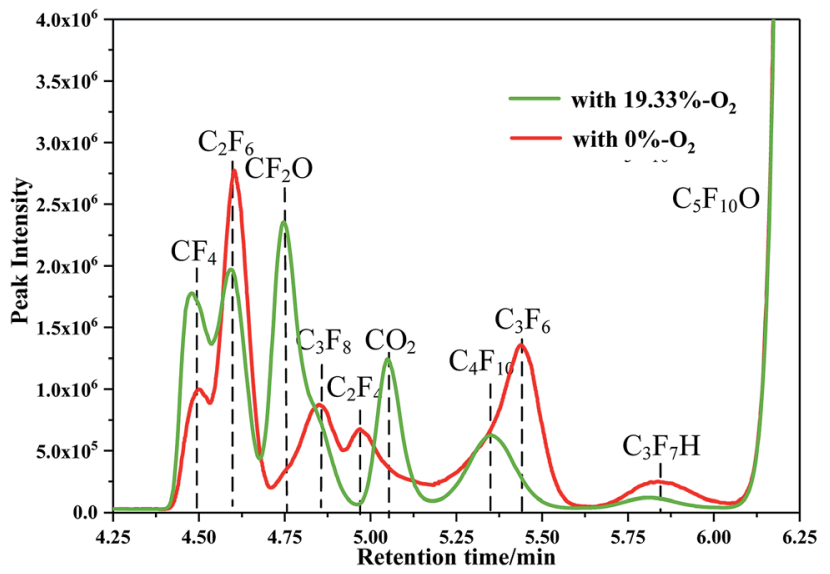

Fig. 7 Components after 60 times breakdown with different oxygen concentrations.

The electrode surfaces with and without oxygen were also compared. As shown in Fig. 8, it was found that a small amount of black substance was adhered to the surface for the gas mixture without oxygen addition after 60 times of breakdown (Fig. 8 left). When the oxygen concentration was $0.5 \%$ or more, only discharge ablation traces could be observed (Fig. 8 right). Therefore, it can be believed that oxygen can inhibit the precipitation of carbon black when $\mathrm{C}_{5} \mathrm{~F}_{10} \mathrm{O}$ decomposes. This may be because the generated carbon particles in the discharge can react with oxygen to produce carbon dioxide in the presence of a high-energy electric field.

Moreover, when the oxygen concentration was $0.5 \%, \mathrm{C}_{2} \mathrm{~F}_{4}$ and $\mathrm{C}_{3} \mathrm{~F}_{6}$ still existed, and $\mathrm{CF}_{2} \mathrm{O}$ was not detected. When the oxygen concentration was increased to $7.5 \%$ or more, $\mathrm{C}_{2} \mathrm{~F}_{4}$ and $\mathrm{C}_{3} \mathrm{~F}_{6}$ were not detected in the decomposition components, whereas $\mathrm{CF}_{2} \mathrm{O}$ began to appear, and its content increased with an increase in oxygen concentration.

Under certain conditions, $\mathrm{O}_{2}$ will react with $\mathrm{C}_{2} \mathrm{~F}_{4}$ and $\mathrm{C}_{3} \mathrm{~F}_{6}$. Several studies have reported the reaction between $\mathrm{O}$ atoms and $\mathrm{C}_{2} \mathrm{~F}_{4}$ or $\mathrm{C}_{3} \mathrm{~F}_{6}$. In the literature, ${ }^{40}$ a mercury lamp was used to irradiate $\mathrm{N}_{2} \mathrm{O}$ to produce $\mathrm{O}$ atoms, which could react with $\mathrm{C}_{2} \mathrm{~F}_{4}$ or $\mathrm{C}_{3} \mathrm{~F}_{6}$ and produce $\mathrm{CF}_{2} \mathrm{O}$. Moreover, in literature, ${ }^{41}$ it has been mentioned that the carbon-carbon double bond $(\mathrm{C}=\mathrm{C})$ of $\mathrm{C}_{2} \mathrm{~F}_{4}$ and $\mathrm{C}_{3} \mathrm{~F}_{6}$ weakens after ionization. Another study ${ }^{42}$ has pointed

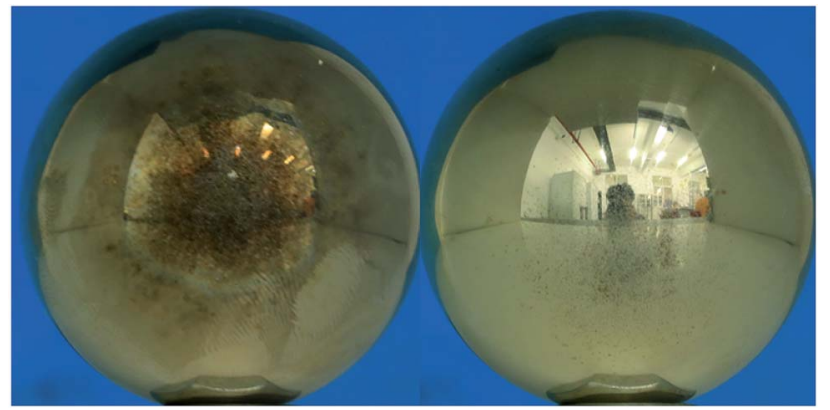

Fig. 8 (Left) Electrode surface after 60 times breakdown of $\mathrm{C}_{5} \mathrm{~F}_{10} \mathrm{O} / \mathrm{N}_{2}$ (right) electrode surface after 60 times breakdown of $\mathrm{C}_{5} \mathrm{~F}_{10} \mathrm{O} / \mathrm{N}_{2} / \mathrm{O}_{2}$. 
out that the $\mathrm{O}$ atoms can attack $\mathrm{C}=\mathrm{C}$ in $\mathrm{C}_{3} \mathrm{~F}_{6}$ leading to the generation of $\mathrm{CF}_{2} \mathrm{O}$ and $\mathrm{CF}_{3} \mathrm{CF}$ :. Moreover, $\mathrm{CF}_{3} \mathrm{CF}$ : will rapidly undergo spin relaxation and then form $\mathrm{C}_{2} \mathrm{~F}_{4}$. Due to the difference in the experimental conditions, these studies can only provide reference for the mechanism of $\mathrm{CF}_{2} \mathrm{O}$ production in our experiments. Based on these studies as well as our team's computational study on the mechanism of $\mathrm{CF}_{2} \mathrm{O}$ production when studying the decomposition characteristics of $\mathrm{CF}_{3} \mathrm{I}^{43}{ }^{43}$ the following pathways can be obtained.

$$
\begin{gathered}
\mathrm{O}_{2}+\mathrm{e} \rightarrow \mathrm{O}^{\cdot}+\mathrm{O}^{-} \\
\mathrm{C}_{3} \mathrm{~F}_{6}+\mathrm{O} \rightarrow \mathrm{CF}_{3} \mathrm{CF}:+\mathrm{CF}_{2} \mathrm{O} \\
\mathrm{CF}_{3} \mathrm{CF}: \rightarrow \mathrm{C}_{2} \mathrm{~F}_{4} \\
\mathrm{C}_{2} \mathrm{~F}_{4} \rightarrow 2 \mathrm{CF}_{2}: \\
\mathrm{CF}_{2}:+\mathrm{O}_{2} \rightarrow \mathrm{CF}_{2} \mathrm{O}+\mathrm{O}^{\circ}
\end{gathered}
$$

\section{Discussion}

The uniformity of the electric field is vulnerable to the conductive particles in the insulating gap and causes local aggrandizement of the electric field. ${ }^{26}$ Although under our experimental conditions, the carbon black adhered on the electrodes had less effect on the dispersion of the breakdown voltage, with an increase in the operating voltage and time, the amount of carbon black increased, and when it accumulated to a certain extent, the insulation safety of the equipment was seriously threatened.

Note that $\mathrm{CF}_{2} \mathrm{O}$ is highly toxic, and its LC50 (Lethal Concentration $50,4 \mathrm{~h}$ ) value is only $270 \mathrm{mg} \mathrm{m}^{-3}$ (inhaled by rats). According to the Globally Harmonized System of Classification and Labelling of Chemicals toxicity classification standard, the acute inhalation toxicity of $\mathrm{CF}_{2} \mathrm{O}$ is level 1 . It has a strong stimulating effect on respiratory mucosa and can cause chemical pneumonia, pulmonary edema, and acute poisoning. Inevitably, the equipment contains a small amount of water, and $\mathrm{CF}_{2} \mathrm{O}$ itself is highly corrosive and easily reacts with water to release highly toxic corrosive gases such as $\mathrm{HF}$, thereby affecting the operating life of the equipment. However, note that although $\mathrm{CF}_{2} \mathrm{O}$ is highly toxic, $\mathrm{CF}_{2} \mathrm{O}$ is irritating as well, and the occurrence of gas leakage is easily detected in time. In addition, $\mathrm{CF}_{2} \mathrm{O}$ is soluble in water and ethanol; thus, the waste gas can be treated harmlessly. Therefore, the toxicity of the decomposition products of a $\mathrm{C}_{5} \mathrm{~F}_{10} \mathrm{O}$ mixture will not affect its application in the power industry to a large extent.

Although the breakdown voltage of $\mathrm{C}_{5} \mathrm{~F}_{10} \mathrm{O} / \mathrm{N}_{2} / \mathrm{O}_{2}$ increases with an increase in oxygen concentration and there is no inflection point value in the curve of breakdown voltage and oxygen concentration, this does not mean that it is reasonable to increase the oxygen concentration or even replace all $\mathrm{N}_{2}$ to increase the insulation strength of $\mathrm{C}_{5} \mathrm{~F}_{10} \mathrm{O} / \mathrm{N}_{2} / \mathrm{O}_{2}$. In fact, when the oxygen concentration is $7.5 \%\left(\mathrm{C}_{5} \mathrm{~F}_{10} \mathrm{O}: \mathrm{O}_{2}\right.$ is $\left.1: 1\right)$, the breakdown voltage of $\mathrm{C}_{5} \mathrm{~F}_{10} \mathrm{O} / \mathrm{N}_{2} / \mathrm{O}_{2}$ reaches $53.20 \%$ that of $\mathrm{SF}_{6}$ under the same conditions (the power frequency breakdown voltage of $\mathrm{SF}_{6}$ tested herein is $26.26 \mathrm{kV}$ ). It is possible to achieve the insulation requirements of the $\mathrm{SF}_{6}$ equipment by increasing the pressure of the $\mathrm{C}_{5} \mathrm{~F}_{10} \mathrm{O}$ gas mixture. ${ }^{44}$ In addition, a partial discharge will inevitably occur during the long-term operation of the equipment, which will lead to the decomposition of the insulation medium. If $\mathrm{C}_{5} \mathrm{~F}_{10} \mathrm{O} / \mathrm{N}_{2} / \mathrm{O}_{2}$ with higher insulation strength is pursued by further increasing the oxygen concentration, the service life of the equipment and the safety of the field personnel will be greatly threatened. For this reason, it is recommended to use oxygen as the second buffer gas for $\mathrm{C}_{5} \mathrm{~F}_{10} \mathrm{O}$; however, it is not recommended to increase the dielectric strength of $\mathrm{C}_{5} \mathrm{~F}_{10} \mathrm{O} / \mathrm{N}_{2} / \mathrm{O}_{2}$ by greatly increasing the oxygen concentration. In the practical application of $\mathrm{C}_{5} \mathrm{~F}_{10} \mathrm{O} / \mathrm{N}_{2} /$ $\mathrm{O}_{2}$, the $1: 1$ ratio of $\mathrm{C}_{5} \mathrm{~F}_{10} \mathrm{O}: \mathrm{O}_{2}$ can be considered.

\section{Conclusion}

In this study, the breakdown voltages of $\mathrm{C}_{5} \mathrm{~F}_{10} \mathrm{O} / \mathrm{N}_{2} / \mathrm{O}_{2}$ at different oxygen concentrations were tested by a gas insulation performance test and gas composition analysis platform. The dispersion of the $\mathrm{C}_{5} \mathrm{~F}_{10} \mathrm{O} / \mathrm{N}_{2} / \mathrm{O}_{2}$ discharge breakdown voltage was analyzed, and the decomposition components were compared. The following conclusions can be obtained:

(1) When the absolute pressure is $0.2 \mathrm{MPa}$ and the partial pressure of $\mathrm{C}_{5} \mathrm{~F}_{10} \mathrm{O}$ is $15 \mathrm{kPa}$, the breakdown voltage of $\mathrm{C}_{5} \mathrm{~F}_{10} \mathrm{O}$ / $\mathrm{N}_{2} / \mathrm{O}_{2}$ and its dispersion increase with an increase in oxygen concentration under a slightly uneven electric field.

(2) The carbon precipitates on the electrode surfaces disappear after multiple discharge breakdowns when $0.5 \%$ or more $\mathrm{O}_{2}$ is added to the gas mixture.

(3) With an increase in the oxygen concentration, the peak area of $\mathrm{CF}_{4}$ in the $\mathrm{C}_{5} \mathrm{~F}_{10} \mathrm{O} / \mathrm{N}_{2} / \mathrm{O}_{2}$ gas mixture gradually approaches that of $\mathrm{C}_{2} \mathrm{~F}_{6}$. When the oxygen content reaches $7.5 \%, \mathrm{C}_{2} \mathrm{~F}_{4}$ and $\mathrm{C}_{3} \mathrm{~F}_{6}$ disappear due to reaction with oxygen to form $\mathrm{CF}_{2} \mathrm{O}$. The addition of oxygen inhibits the formation of $\mathrm{C}_{2} \mathrm{~F}_{6}, \mathrm{C}_{3} \mathrm{~F}_{8}, \mathrm{C}_{4} \mathrm{~F}_{10}$ and $\mathrm{C}_{3} \mathrm{~F}_{7} \mathrm{H}$ to a certain extent.

(4) $\mathrm{CF}_{2} \mathrm{O}$ generated after the $\mathrm{C}_{5} \mathrm{~F}_{10} \mathrm{O} / \mathrm{N}_{2} / \mathrm{O}_{2}$ discharge breakdown is highly corrosive and extremely toxic, which is harmful to the equipment and personnel. Therefore, it is not preferable to increase the dielectric strength of $\mathrm{C}_{5} \mathrm{~F}_{10} \mathrm{O} / \mathrm{N}_{2} / \mathrm{O}_{2}$ by further increasing the oxygen concentration. The recommended $\mathrm{C}_{5} \mathrm{~F}_{10} \mathrm{O}: \mathrm{O}_{2}$ ratio is $1: 1$.

\section{Conflicts of interest}

There are no conflicts to declare.

\section{Acknowledgements}

The current work was supported by the National Natural Science Foundation of China (No. 51707137, 51877157).

\section{References}

1 D. Chen, X. Zhang, J. Tang, et al., Using Single-Layer $\mathrm{HfS}_{2}$ as Prospective Sensing Device Toward Typical Partial Discharge 
Gas in $\mathrm{SF}_{6}$-Based Gas-Insulated Switchgear, IEEE Trans. Electron Devices, 2019, 66(1), 689-695.

2 J. Chu, X. Wang, D. Wang, et al., Highly selective detection of sulfur hexafluoride decomposition components $\mathrm{H}_{2} \mathrm{~S}$ and $\mathrm{SOF}_{2}$, employing sensors based on tin oxide modified reduced graphene oxide, Carbon, 2018, S0008622318303968.

3 H. Cui, X. Zhang, G. Zhang, et al., Pd-doped $\mathrm{MoS}_{2}$ monolayer: a promising candidate for DGA in transformer oil based on DFT method, Appl. Surf. Sci., 2019, 470, 1035-1042.

4 D. Wang, X. Wang, A. Yang, et al., A first principles theoretical study of the adsorption of $\mathrm{SF}_{6}$, decomposition gases on a cassiterite (110) surface, Mater. Chem. Phys., 2018, 212, 453-460.

5 D. Chen, X. Zhang, J. Tang, et al., Pristine and Cu decorated hexagonal InN monolayer, a promising candidate to detect and scavenge $\mathrm{SF}_{6}$ decompositions based on first-principle study, J. Hazard. Mater., 2019, 363, 346-357.

6 A. V. Tatarinov, I. V. Bilera, S. V. Avtaeva, et al., Dielectric Barrier Discharge Processing of trans- $\mathrm{CF}_{3} \mathrm{CH}=\mathrm{CHF}$ and $\mathrm{CF}_{3} \mathrm{C}(\mathrm{O}) \mathrm{CF}\left(\mathrm{CF}_{3}\right)_{2}$, Their Mixtures with Air, $\mathrm{N}_{2}, \mathrm{CO}_{2}$ and Analysis of Their Decomposition Products, Plasma Chem. Plasma Process., 2015, 35(5), 845-862.

7 X. Zhang, Z. Cui, Y. Li, et al., Abatement of $\mathrm{SF}_{6}$ in the presence of $\mathrm{NH}_{3}$ by dielectric barrier discharge plasma, $J$. Hazard. Mater., 2018, 360, 341-348.

8 P. Simka and N. Ranjan, Dielectric strength of C5 perfluoroketone,//Proceedings of the 19th International Symposium on High Voltage Engineering, Pilsen, Czech Republic, 2015, pp. 23-28.

9 X. Zhang, Y. Li, D. Chen, et al., Dissociative adsorption of environment-friendly insulating medium $\mathrm{C}_{3} \mathrm{~F}_{7} \mathrm{CN}$ on $\mathrm{Cu}$ (111) and $\mathrm{Al}$ (111) surface: a theoretical evaluation, Appl. Surf. Sci., 2018, 434, 549-560.

$10 \mathrm{Y}$. Deng, D. Xiao and J. Chen, Insulation performance of $\mathrm{CF}_{3} \mathrm{I}-\mathrm{N}_{2}$ gas mixtures as alternative for $\mathrm{SF}_{6}$ in GIS/C-GIS, High Voltage Eng., 2013, 39(9), 2288-2293.

11 D. Chen, X. Zhang, J. Tang, et al., Noble metal (Pt or Au)doped monolayer $\mathrm{MoS}_{2}$ as a promising adsorbent and gassensing material to $\mathrm{SO}_{2}, \mathrm{SOF}_{2}$ and $\mathrm{SO}_{2} \mathrm{~F}_{2}$ : a DFT study, Appl. Phys. A: Mater. Sci. Process., 2018, 124(2), 194.

12 L. G. Christophorou and R. J. Van Brunt, $\mathrm{SF}_{6} / \mathrm{N}_{2}$ mixtures: basic and HV insulation properties, IEEE Trans. Dielectr. Electr. Insul., 1995, 2(5), 952-1003.

13 H. Cui, X. Zhang, D. Chen, et al., Adsorption mechanism of $\mathrm{SF}_{6}$, decomposed species on pyridine-like $\mathrm{PtN}_{3}$, embedded CNT: a DFT study, Appl. Surf. Sci., 2018, S0169433218309280.

14 J. Xiong, X. Li, J. Wu, et al., Calculations of total electronimpact ionization cross sections for Fluoroketone $\mathrm{C}_{5} \mathrm{~F}_{10} \mathrm{O}$ and Fluoronitrile $\mathrm{C}_{4} \mathrm{~F}_{7} \mathrm{~N}$ using modified Deutsch-Märk formula, J. Phys. D: Appl. Phys., 2017, 50(44), 445206.

15 Y. Li, X. Zhang, D. Chen, et al., Theoretical study on the interaction between C5-PFK and Al ( $\left.\begin{array}{lll}1 & 1 & 1\end{array}\right), A g\left(\begin{array}{lll}1 & 1 & 1\end{array}\right)$ : a comparative study, Appl. Surf. Sci., 2019, 464, 586-596.

16 C. Zhang, H. Shi, L. Cheng, et al., First principles based computational scheme for designing new $\mathrm{SF}_{6}$ replacements, IEEE Trans. Dielectr. Electr. Insul., 2016, 23(5), 2572-2578.
17 Y. Li, X. Zhang, S. Tian, et al., Insight into the decomposition mechanism of $\mathrm{C}_{6} \mathrm{~F}_{12} \mathrm{O}-\mathrm{CO}_{2}$ gas mixture, Chem. Eng. J., 2019, 360, 929-940.

18 H. Katagiri, H. Kasuya, H. Mizoguchi, et al., Investigation of the performance of $\mathrm{CF}_{3} \mathrm{I}$ Gas as a Possible Substitute for $\mathrm{SF}_{6}$, IEEE Trans. Dielectr. Electr. Insul., 2008, 15(5), 1424-1429.

19 Y. K. Deng and D. M. Xiao, Analysis of the insulation characteristics of $\mathrm{c}-\mathrm{C}_{4} \mathrm{~F}_{8}$ and $\mathrm{N}_{2}$ gas mixtures by Boltzmann equation method, Eur. Phys. J.: Appl. Phys., 2012, 57(2), 20801.

20 R. Ullah, A. Rashid, A. Rashid, et al., Dielectric characteristic of dichlorodifluoromethane (R12) gas and mixture with $\mathrm{N}_{2} /$ air as an alternative to $\mathrm{SF}_{6}$ gas, High Voltage, 2017, 2(3), 205-210.

21 D. Chen, X. Zhang, J. Tang, et al., High selective $\mathrm{SO}_{2}$ gas sensor based on monolayer $\beta$-AsSb to detect $\mathrm{SF}_{6}$ decompositions, IEEE Sens. J., 2018, 1.

22 Y. Li, X. Zhang, Q. Chen, et al., Study on the thermal interaction mechanism between $\mathrm{C}_{4} \mathrm{~F}_{7} \mathrm{~N}-\mathrm{N}_{2}$ and copper, aluminium, Corros. Sci., 2019, 153, 32-46.

23 Y. Deng and D. Xiao, Analysis of the insulation characteristics of $\mathrm{CF}_{3} \mathrm{I}$ gas mixtures with $\mathrm{Ar}, \mathrm{Xe}, \mathrm{He}, \mathrm{N}_{2}$, and $\mathrm{CO}_{2}$ using Boltzmann equation method, Jpn. J. Appl. Phys., 2014, 53(9), 096201.

24 D. Chen, J. Tang, X. Zhang, et al., Detecting decompositions of sulfur hexafluoride using $\mathrm{MoS}_{2}$ monolayer as gas sensor, IEEE Sens. J., 2018, 1.

25 Y. Li, X. Zhang, J. Zhang, et al., Assessment on the toxicity and application risk of $\mathrm{C}_{4} \mathrm{~F}_{7} \mathrm{~N}$ : a new $\mathrm{SF}_{6}$ alternative gas, $J$. Hazard. Mater., 2019, 368, 653-660.

26 L. Niemeyer, A systematic search for insulation gases and their environmental evaluation,//Gaseous Dielectrics VIII. Springer, Boston, MA, 1998, pp. 459-464.

27 Y. Li, X. Zhang, S. Xiao, et al., Decomposition properties of $\mathrm{C}_{4} \mathrm{~F}_{7} \mathrm{~N} / \mathrm{N}_{2}$ gas mixture: an environmentally friendly gas to replace $\mathrm{SF}_{6}$, Ind. Eng. Chem. Res., 2018, 57(14), 5173-5182.

28 Y. Fu, X. Wang, X. Li, et al., Theoretical study of the decomposition pathways and products of C5perfluorinated ketone (C5 PFK), AIP Adv., 2016, 6(8), 085305.

29 M. Saxegaard, M. Kristoffersen and P. Stoller, et al., Dielectric properties of gases suitable for secondary medium voltage switchgear, CIRED Paper, 2015, p. 926.

30 M. Kristoffersen, T. Endre, M. Saxegaard, et al., Ring main units with eco-efficient gas mixtures: field experience, CIRED-Open Access Proceedings Journal, 2017, 2017(1), 412415.

31 F. Wang, X. Fu, G. Han, et al., Insulation performance of $\mathrm{C}_{5} \mathrm{~F}_{10} \mathrm{O} / \mathrm{CO}_{2}$ gas mixture, Gaodianya Jishu, 2017, 43(3), 715720.

32 M. Aints, I. Jõgi, M. Laan, et al., Effective ionization coefficient of C5 perfluorinated ketone and its mixtures with air, J. Phys. D: Appl. Phys., 2018, 51(13), 135205.

33 A. Chachereau, A. Hösl and C. M. Franck, Electrical insulation properties of the perfluoroketone $\mathrm{C}_{5} \mathrm{~F}_{10} \mathrm{O}, \mathrm{J}$. Phys. D: Appl. Phys., 2018, 51(33), 335204. 
34 X. Zhang, Y. Li, S. Xiao, et al., Decomposition mechanism of $\mathrm{C}_{5} \mathrm{~F}_{10} \mathrm{O}$ : an environmentally friendly insulation medium, Environ. Sci. Technol., 2017, 51(17), 10127-10136.

35 X. Zhang, Y. Li, S. Tian, et al., Decomposition mechanism of the $\mathrm{C} 5-\mathrm{PFK} / \mathrm{CO}_{2}$ gas mixture as an alternative gas for $\mathrm{SF}_{6}$, Chem. Eng. J., 2018, 336, 38-46.

36 M. Hyrenbach, T. A. Paul and J. Owens, Environmental and safety aspects of airplus insulated GIS, CIRED-Open Access Proceedings Journal, 2017, 2017(1), 132-135.

37 Z. Guo, X. Li, B. Li, et al., Dielectric properties of C5-PFK mixtures as a possible $\mathrm{SF}_{6}$ substitute for $\mathrm{MV}$ power equipment, IEEE Trans. Dielectr. Electr. Insul., 2019, 26(1), 129-136.

38 P. C. Stoller, C. B. Doiron, D. Tehlar, et al., Mixtures of $\mathrm{CO}_{2}$ and $\mathrm{C}_{5} \mathrm{~F}_{10} \mathrm{O}$ perfluoroketone for high voltage applications, IEEE Trans. Dielectr. Electr. Insul., 2017, 24(5), 2712-2721.

39 L. Zhong, M. Rong, X. Wang, et al., Compositions, thermodynamic properties, and transport coefficients of high-temperature $\mathrm{C}_{5} \mathrm{~F}_{10} \mathrm{O}$ mixed with $\mathrm{CO}_{2}$ and $\mathrm{O}_{2}$ as substitutes for $\mathrm{SF}_{6}$ to reduce global warming potential, $A I P$ Adv., 2017, 7(7), 075003.

40 K. A. Kobe, The properties of gases and liquids, Phys. Today, 1959, 12(4), 38-40.

41 G. K. Jarvis, K. J. Boyle, C. A. Mayhew, et al., Threshold Photoelectron-Photoion Coincidence Spectroscopy of Perfluorocarbons. 2. Unsaturated and Cyclic Perfluorocarbons $\mathrm{C}_{2} \mathrm{~F}_{4}, \mathrm{C}_{3} \mathrm{~F}_{6}, 2-\mathrm{C}_{4} \mathrm{~F}_{8}$, and $\mathrm{c}-\mathrm{C}_{4} \mathrm{~F}_{8}, J$. Phys. Chem. A, 1998, 102(19), 3230-3237.

42 D. Saunders and J. Heicklen, Some Reactions of Oxygen Atoms. I. $\mathrm{C}_{2} \mathrm{~F}_{4}, \mathrm{C}_{3} \mathrm{~F}_{6}, \mathrm{C}_{2} \mathrm{H}_{2}, \mathrm{C}_{2} \mathrm{H}_{4}, \mathrm{C}_{3} \mathrm{H}_{6}, 1-\mathrm{C}_{4} \mathrm{H}_{8}, \mathrm{C}_{2} \mathrm{H}_{6}, \mathrm{c}-$ $\mathrm{C}_{3} \mathrm{H}_{6}$, and $\mathrm{C}_{3} \mathrm{H}_{8} 1 \mathrm{a}$, J. Phys. Chem., 1966, 70(6), 1950-1958.

43 S. Xiao, Y. Li, X. Zhang, et al., Formation mechanism of $\mathrm{CF}_{3} \mathrm{I}$ discharge components and effect of oxygen on decomposition, J. Phys. D: Appl. Phys., 2017, 50(15), 155601.

44 X. Li, D. Yun, H. Zhao, et al., Insulation Performance and Application of Environment-friendly Gases Mixtures of $\mathrm{C}_{4} \mathrm{~F}_{7} \mathrm{~N}$ and $\mathrm{C}_{5} \mathrm{~F}_{10} \mathrm{O}$ with $\mathrm{CO}_{2}$, High Voltage Eng., 2017, 43(3), 708-714. 